\title{
A INDEPENDÊNCIA EM GOIÁS (*).
}

\author{
SERGIO PAULO MOREYRA \\ do Departamento de História do Instituto de Ciên- \\ cias Humanas e Letras da Universidade Federal de \\ Goiás.
}

\section{INTRODUÇÃO.}

A Conjuntura. - No final da segunda década do século XIX, Goiás teria pouco mais de cinquenta mil habitantes, dos quais cerca de vinte mil eram escravos. A Capitania estava dividida em apenas duas comarcas. A do sul, com sede na capital, Goiás, concentrava $61 \%$ da população total (entre os quais $82 \%$ de toda a população branca. No território da comarca do sul, apenas o sudoeste era um vazio total. Ao norte, onde a sede da comarca era a vil ade São João da Palma, a população concentrava-se a nordeste. Descendo os rios, além de Porto Real só existia a povoação da Carolina (1).

A decadência da mineração e a falta de alternativas econômicas provocaram a dispersão da população - que se concentrara em diminutos arquipélagos demográficos - da Capitania, a partir das últimas décadas do século XVIII. A insignificância da comercialização levou à produção de bens exportáveis para mercados litorâneos. Essa procura de opções que permitissem a sobrevivência fez surgir uma insólita economia açucareira (2), ampliou a produção de cereais e ativou o interesse pela navegação dos rios que conduziam ao Pará.

Algumas décadas mostraram a impossibilidade de exportação de excedentes agrícolas, pois os cursos dos rios não permitiam navega-

(*) . - Comunicação apresentada na $3^{\text {a }}$ Sessão de Estudos, no dic 7 de julho de 1972 (Nota da Redação). atuais.

(1). - Os limites políticos da Capitania eram bem mais amplos que os

(2). - Ainda em 1828 existiam em funcionamento 133 engenhos e 21 engenhocas. Cf. SOUZA (Luís Antônio da Silva e), Memórias Estatísticas da Província de Goiás, Rio de Janeiro, Tịpografia Nacional, 1832, passim. 
ção regular, a precariedade e alto custo da transporte terrestre impediam que os produtos fossem colocados nos mercados consumidores a preços competitivos (3).

Nesse quadro de impossibilidades, a pecuária aflorou como a única solução econômica, pelo baixo custo de produção e por ser autotransportável. Na terceira década do século XIX, mais de seiscentas fazendas de criar espalhavam-se pelas chapadas e cerrados, exportando anualmente cerca de 20.000 cabeça sde gado vacum e pequena quantidade de muares e cavalares (4).

A lenta afirmação da economia agrária reduziu progressivamente a significação dos núcleos urbanos, acelerando a decadência iniciada com o declínio da mineração. Alguns arraiais desapareceram, e os remanescentes, sobreviveram debilitados e semi-despovoados. Com exceção da cidade de Goiás, haviam-se transformado em entrepostos - visitados para a aquisição dos generos indispensáveis - e centros das periódicas manifestações coletivas de religiosidade.

A esse processo de ruralização corresponderam, uma diluição dos padróes de vida anteriormente permitidos pelo ouro, um isolamento físico decorrente da rudimentar auto-suficiência agrária, um enfraquecimento das articulações sócio-políticas, uma estagnação tecnológica e dos níveis de aspiração da população livre. E mais, o surgimento de novas formas de servidão e dependência, pois a mão-deobra escrava - inadequada para o trabalho livre, de criar extensivamente - exigia substituição.

Assim, no momento da Independência, o acesso ao conhecimento e compreensão do que ocorria nas outras províncias, no Rio de laneiro e na Metrópole, estava restrito a um pequeno número de grandes proprietários (4) e ao estamento burocrático, concentrado na capital.

(3). - Em 1824, o presidente da província queixava-se da impossibilidade de exploração dos recursos minerais e agrícolas, pela distância a çue ficavam os mercados e portos de mar. Cf. Serviço de Documentação do Estado de Goiás, Livro 12\% para o Império, Estrangeiros e Marinha, "Ofício sobre o deplorável estado a que se acha reduzida esta província", 9-11.

(4). - Exportados principalmente para ctntros intermediários do norte de Minas Geraịs e do oeste da Bahia. Cf, SOUZA (Luís Antôniu di Silva e), op. cit., passim.

(5) : - Os maiores criadores mantinham suas próprias tropas para adquirir sal na Bahia. Seus tropeiros levavam sua correspondência e traziam de lá os jornais e notícias que pudessem recolher. 
O último Capitão General. - Desde outubro de 1820 estava em Goiás o último governador colonial, Manuel Inácio de Sampaio. Suas iniciativas para reorganizar a administração haviam provocado irritação geral, que cresceu até fazer dele o alvo físico de um descontentamento que se acumulara durante as décadas anteriores.

Em 1803 já era perceptível o descontentamento contra um sistema administrativo que, montado quase um século antes para supervisionar e fiscalizar a sociedade mineradora, mostrava-se ineficiente para responder às necessidades e reivindicações da nova sociedade agrária. Nesse ano, uma circunstancial desinteligência entre o Capitão General João Manuel de Menezes e a Câmara de Vila Boa levara os camaristas ao extremo de tentar prender o Governador. Não tendo conseguido controlar a tropa, a Câmara foi sitiada e o fato não ultrapassou o nível de um incidente.

Após um período em que os conflitos foram amenizados pela eficiência do Capitão General D. Francisco de Assis Mascarenhas, a inércia de seu sucessor, Fernando Delgado Freire de Castilho, reativou as contradições. Os sentimentos antigovernistas fundavam-se tanto nessa inércia ccmo no poder excessivo que tinham os governadores. Quando em 1816 um conflito de interesses levou os proprietários rurais do extremo sul - a região situada entre os rios Paranaíba e Grande, hoje o Triângulo Mineiro - a requererem do Rei sua anexação à comarca mineira de Paracatu, o atendimento do pedido repercutiu fortemente na capital, tornando mais flagrante aos olhos locais o desinteresse do governo pela Capitania empobrecida.

Quando Manuel Inácio de Sampaio assumiu o governo, tomou algumas decisões que o incompatibilizaram fortemente com o estamento burocrático, com os fazendeiros e negociantes. Verificando a contabilidade da Companhia de Mineração de Anicuns - empresa de capital misto criada alguns anos antes - e percebendo graves inexatidões, acusou publicamente seus administradores de improbidade e mandou reter seus salários na Junta de Fazenda. Isso repercutiu com maior intesidade do que esperava, pois o entrelaçamento das famílias e dos interesses fazia, como numa reação em cadeia, qualquer acusação individual transformar-se em afronta coletiva (6).

A análise da situação orçamentária e dạ reservas financeiras levou-o a mandar sustar por completo o pagamento de todas as dívidas contraídas pelo governo antes de sua chegada. Algum tempo depois procurou resolver o problema - sob pressão dos interessados -

(6). - SDEG, Livro $1^{o}$ de Registro Geral (1820-1824), 57. 
pagando todos os credores e funcionários com bilhetes de crédito de circulação livre no território da Capitania (7). Como os comerciantes da capital viviam dos fornecimentos à tropa e ao funcionalismo, viram-se forçados a receber os bilhetes e aceitar o desaparecimento de seus capitais, só recompostos alguns anos depois, quando tais papéis terminaram por ser recolhidos.

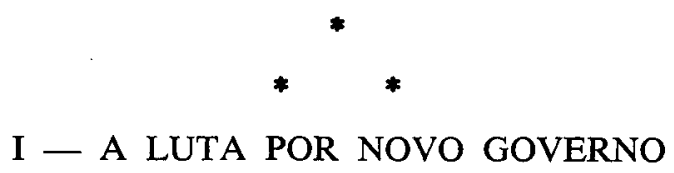

O Início da Crise. - Quando o correio da Corte chegou à capital na noite de 24 de abril de 1821, trazendo informações precisas sobre o movimento constitucionalista português, toda a magrugada foi ocupada por reuniões em diversas casas da cidade.

No dia seguinte, o Capitão General deu início ao que se transformaria numa guerra de proclamações, que se multiplicariam ao longo de dois anos. Fez afixar um pedido de moderação em todos os locais de afluência, solicitando reflexão e cuidado na escolha dos deputados que deveriam ser eleitos às Cortes (8), esperando que ao acenar a promessa eleitoral os ânimos se contivessem.

$\mathrm{Na}$ mesma semana, entre as festas de rua e as cerimônias dos juramentos de fidelidade às Cortes, foram expedidas ordens de convocação das juntas eleitorais das freguesias. Escolhidos os eleitores, deveriam reunir-se na capital em agosto (9).

Entretanto, os meses seguintes foram agitados pelos radicais. A princípio disfarçadamente e depois às claras, promoviam reuniões, faziam comícios e afixavam violentas proclamações anti-portuguesas pelos muros e até nas paredes do palácio.

Existiam dois grupos coordenados. Um, civil, liderado pelos padres Luís Bartolomeu Marques (10), José Cardoso de Mendonça e

(7). - SDEG, Livro $2^{\circ}$ para o Império, Estrangeiros e Marinha (18241827), 22v-31v.

(8). - SDEG, Livro $1^{o}$ de Registro Geral (1820-1824), 60v-61

(9). - AlENCASTRE (José Martins Pereira de), "Anais da Província de Goiás". In Revista do Instituto Histórico e Geográfico Brasileiro, tomo 28, 1865,116 .

(10) . - O padre Marques era um mulato culto, matemático, ativista radical, que pouco depois seria marginalizado do processo político. $O$ seu jacobinismo marcou toda ação política que desenvolveu. Em 1831, sendo vice-presidente da província, voltaria a comandar a luta contra os portugueses, fazendo depor o presidente Miguel Lino de Morais, que era português. 
Lucas Freire de Andrade. O outro, militar e agindo entre a tropa, era dirigido pelo Capitão Felipe Antonio Cardoso (11), secundado pelo Capitão Francisco Xavier de Barros e pelo Soldado Felizardo Nazaré.

Sentindo-se incomodado pela ação do Padre Marques (12), o Capitão General fê-lo vir ao palácio e repreendeu-o publicante. O padre, ciente do temor que inspirava, redobrou seus esforços pela sublevação.

Mas embora soubessem contra quem deveriam lutar, não se deliniam a respeito do objetivo da luta. Invenctivavam contra a dominação e contra a presença lusa em qualquer função pública, sem conhecerem os rumos a tomar. Em uma província central, condicionada permanentemente a depender da direção, das iniciativas, das importações e dos modismos litorâneos; em uma região onde se recebiam todas as coisas de segunda mão, através de intermediários, era necessário que alguma forma de orientação lhes fosse dada, a partir da qual estruturarem a ação.

Receberam esse impulso no final de julho, quando passou por Goiás o correio da Corte, com destino a Màto Grosso. A renovação das informações sobre o que se passava no Rio e o conhecimento de que $\mathrm{cm}$ São Paulo já se constituíra um governo provisório, levaram o Padre Marques e o Capitão Cardoso a dirigirem seu esforço no sentido de convencer o povo a forçar a criação local de um governo semelhante.

O Governador Manuel Inácio de Sampaio - que se limitava a agir conforme as instruções que recebia - por não ter ordens do Regente a esse respeito, procurava persuadir publicamente a todos da necessidade de fidelidade às Cortes e confiança no governo (13).

A Rebelião Frustrada. - Apesar da ação dos radicais, Sampaio teve condições para realizar a eleição dos deputados, a 7 de agosto. Embora não ocorressem pressões anormais, os nomes de sua prefe-

(11). - O capitão Cardoso era membro de uma das famílias mais ricas do norte, os maiores exportadores de gado de Arraias e São Domingos. Estava fortemente influenciado pelas idéias políticas que revolucionaram : Bahid e Pernambuco, de onde recebia notícias regularmente, através de seus tropeiros. Cf. BRASIL (Antônio Americano do), O Brigadeiro Felipe. Goiás, $1924,18 \mathrm{p}$.

(12) . - O governador temeu mais o padre que o militar por ainda the se:em fiéis os comandantes da tropa. Cf. ALENCASTRE (José Martins Pereira de), op. cit., 117.

(13). - Idem, idem, 118 
rência foram sancionados: o Desembargador Joaquim Teotônio Segurado (14), o Cônego Luís Antônio da Silva e Souza e para suplente, Plácido Moreira de Carvalho.

O Capitão General manobrara com habilidade, esperando que os eleitos viessem auxiliá-lo a confirmar sua autoriciade. Propôs o nome de Segurado porque devendo ser eleitos um deputado de cada Comarca, o representante natural do norte seria o Ouvidor. O segundo deputado, respeitado por todos, além de ser o Governador da Prelazia - como procurador do Bispo Cego, D. Francisco, que ainda não chegara a Goiás - era brasileiro e seu amigo (15). O suplente, sobrinho de um padre da Capital, era um goiano ausente que residia entre os índios, nos sertões fronteiriços de Maranhão e Pará, a quem Sampaio conhecera quando governara o Ceará (16).

Se as eleições foram aceitas pela maioria, para quem eram o indício de que o despotismo começava a declinar, fizeram que os rebeldes objetivassem sua ação. O padre Marques e o Capitão Cardoso prepararam um golpe que deveria eclodir às nove horas da noite de 14 de agosto. Nessa noite Sampaio deveria ser preso e assumiriam o governo.

Feitos todos os preparativos, ao anoitecer todos estavam em posições pré-determinadas aguardando o momento de agir. Às oito horas da noite, surpresos, perceberam que a tropa movimentava-se pela cidade, ocupando os pontos estratégicos e pouco depois o Capitão Cardoso cruzava as ruas escoltado por um pelotão comandado pelo Tenente-Coronel Luís da Costa Freire de Freitas, a maior autoridade militar da Capitania.

(14). - O desembargador Segurado chegara a Goiás em 1805, nomeado ouvidor geral da capitania. Foi transferido para a ouvidoria do norte em 1809, com a criação dessa comarca. Fixando residência na Palma, aí se casou e identificou-se tanto com os interesses e problemas da região que tornou-se o humem de maior prestígio do norte, fato ainda mais acentuado pelo poder da família de sua mulher, os Pereira de Lemos.

(15). - Silva e Souza não era só amigo de Sampaio como o admirava . Essa admiração transparece nos versos laudatórios que lhe dedicou. Cf. AI.ENCASTRE (José Martins Pereira de), "Traços Biográficos de Silva e Souza", in Revista do Instituto Histórico e Geográfico Brasileiro, tomo 30, 1867, 241-256.

(16). - AlENCASTRE (José Martins Pereira de), "Anais da Província de Goiás", in Revista do Instituto Histórico e Geográfico Brasileiro, tomo 28, 1865, 119 e SDEG, Livro de Ofícios da Junta Interina de Governo para Lisboa (1822), 3-12v. 
O Capitão General recebera, depois do anoitecer, uma denúncia (17) sobre o golpe e seus chefes. Depois de despachar com urgência ordens para a tropa, mandara prender o Capitão Cardoso, o Padre Marques e o Soldado Nazaré. Apenas o padre conseguira escapar.

$\mathrm{Na}$ mesma noite, convocando o Ouvidor Paulo Couceiro de Almeida Homem, ordenou a abertura de devassa contra os seis cabeças da rebeliāo, acusados da tentativa de implantar um govreno ilegal. Tomados os depoimentos, os dois militares foram remetidos à cadeia, onde permaneceram presos e incomunicáveis por uma semana (18).

No decurso dessa semana ,a maior parte dos conspiradores acovardou-se, inclusive o Capitão Xavier de Barros - que foi à presença de Sampaio jura-lhe obediência. Este, recompondo sua autoridade, sentia-se temeroso da ação que os rebeldes pudessem desenvolver no futuro, mas não se dispunha a assumir a responsabilidade de um encarceramento coletivo. Passado o momento crítico, evitou agir contra os que não haviam sido presos. Sabia que os revoltosos eram partidários da independência total de Portugal, enquanto ele próprio conforme demonstraram suas ações futuras - limita-se a seguir as instruções recebidas da Regência (19).

Quando a indiferença começava a generalizar-se e o Padre Marques - precavido contra a fragilidade de seus companheiros - limitava-se a escrever cartas a algumas pessoas do interior, na esperança de uma reação vinda dos arraiais, um negociante chegou do Rio de Janeiro trazendo cópia de um decreto das Cortes. Esse documento autorizava o povo a instalar governos provisórios nos locais cujos governantes se recusassem ao reconhecimento da autoridade parlamentar .

Distorcendo o sentido do decreto, reiniciaram-se oz comícios, as reuniões clandestinas e os pasquins e proclamações voltaram a amanhecer nos muros. O Governador replicava tentando convencer o povo de que o texto era aplicável aos que resistissem às ordens das Cortes, o que não ocorrera em Goiás, onde os deputados já haviam sido eleitos.

(17). - A denúncia foi feita por uma mulher, Maria Gertrudes Laura, o que permite supor que tivesse agido por instrução de alguém que tivesse conhlecimento do plano. Cf. ALENCASTRE (José Martins Pereira de), op. cit., 119.

(18) . - SDEG, Livro de Ofícios da Junta Interina de Govêrno para Lisboa (1822) 3-12v e Livro $1^{o}$ de Registro Geral (1820-1824).

(19). - AlenCASTRE (José Martins Pereira de); op. cit., 121 
A Câmara, cujos componentes temiam tanto o radicalismo do padre Marques como a presença da tropa armada, enviou ao Governador um ofício, a 21 de agosto, pedindo-lhe que esquecesse o passado e evitasse a ampliação da discórdia. Sendo público o envio desse documento, o povo ajuntou-se em frente ao palácio, esperando uma re: posta. De tal forma estavam amedrontados que, com a demora, começaram a chamar por Sampaio. Este saiu, discutiu com os principais e sob o aplauso coletivo decidiu-se expulsar da cidade os cabeças da revolta (20), estabelecendo-se o prazo de oito dias para o cumprimento da ordem e tendo todos assinado documento que legitimava a decisão.

Com a expulsão des:es homens, efetivada no início de setembro, deixou de existir a única iniciativa organizada na capital, francamente favorável à Independência. Os protestos posteriores - dos que permaneceram - de que haviam apoiado o Capitão General sob coação física, tiveram a finalidade de provar a arbitrariedade de Sampaio e justificar, perante as Cortes e o Regente, o rumo que os acontecimentos tomaram depois de setembro. Em nenhum momento, os homens que posteriormente assumiriam o controle do poder político regional, mostraram apoiar as idéias do padre Marques e do Capitão Cardoso, da mesma forma que não procuraram resguardá-los da ação policial. Na verdade, tudo indica que também para eles, eram duas figuras indesejáveis.

$O$ enfraquecimento das articulações inter-regionais, a alienação provocada pela ruralização e a limitação do número de pessoas em condições de tomar atitudes políticas, não impediram que no momento da Independência existissem na Capitania, com relação a ela, diversos grupos e atitudes que se superpunham. Um pequeníssimo grupo de letrados, liderados pelo padre Luís Bartolomeu Marques e pelo capitão Felipe Antônio Cardoso, aspiravam à separação total de

(20). - O capitão Xavier de Barros seguiria para o Registro de Santa Maria, o padre Mendonça para a Aldeia de Formiga e Duro, o canitão Cardoso para sua fazenda em Arraias, o padre Marques para qualquer lugar a mais de cinquenta léguas da capital. O padre Andrade declarou no momento que abandonaria a capitania, o que não fez. Mais tarde, os homens que virim a compor o governo provisório diriam ter assentido a essa decisão por estarem cercados de armas, e que sob a mesma coação assinaram requerimentos que pediam a permanência de Sampaio no govêrno da capitania por mais seis anos. Cf. SDEG, Livro de Ofícios da Junta Interina de Govêrno para Lisboa (1822), 3-12v e ALENCASTRE (José Martins Pereira de), op. rit., 1.23-125. 
Portugal. Um grupo menor ainda, cujos mentores eram o Juiz de Fora Manuel Antônio Galvão e o secretário do governo, Antônio Pedro de Alencastro, procurou disseminar idéias repubicanas na capital (21).

Acima desses pequenos grupos existia um grupo maior que veio a predominar, formado pelos homens mais influentes da capital e de Meia Ponte - que representavam os grandes proprietários do sul e no qual pontificavam o padre Luís Gonzaga de Camargo Fleuri e o capitão José Rodrigues Jardim (22). Esse grupo, moderado, nunca teve iniciativas próprias relativas à Independência, limitando-se a agir conforme a situação evoluia no Rio de Janeiro. Seus objetivos eram ter o mando na Província e mantê-la unida, conforme qualquer orientação governamental. Compunham um grupo pragmático, que sabia o que desejava, que utilizou todos os meios para tomar o poder, mas que nunca se mostrou inclinado a levar suas iniciativas além de limites aprováveis pela Corte.

(21). - Galvão viria a ter uma extensa e intensa vida política, corno deputado, senador, conselheiro de Estado, presidente de províncias, mi istro e diplomata. Cf. JAVARI (Barão de), Organizações e Programas Miristeriais, Rio de Janeiro, Arquivo Nacional, 1962, 2a edição, passim, e GUIMARÃES (Argeu), Dicionário Bio-Bibliográfico Brasileiro, Rio de Janeiro.

Alencastro, que deixou a capitania pouco depois, reapareceria na vida política regional em 1834, nomeado pela Regência para a presidência de Mato Grosso. Cf. CORREIA FILHO (Virgílio), História de Mato Giosso. Rio de Janeiro, Instituto Nacional do Livro, 1969, 490-493.

(22) . - O padre Gonzaga, muito hábil e cultivado, além do prestígio pessoal que desfrutava, era o mentor e portavoz do homem de maior fortuna da província, Joaquim Alves de Oliveira, sargento-mor e comandante de Meia Ponte. Mais tarde, foi presidente e deputado. Teve filhos de três mu!heres, sendo ascendente de algumas das mais extensas famílias da província.

Jardim, dono de extrema habilidade política, era o vereador máis a-tigo e um dos juízes ordinários da capital, apesar de contar apenas 39 anos. Trabalhando sutilmente nos bastidores, tornou-se o chefe político da província. Foi o primeiro nome de uma oligarquia que, com breves interrupçóes ainda controla o poder político em Goiás. Casado com D. Angela Ludovico de Almeida, era irmão do padre Manuel Rodrigues Jardim, que foi deputado às Côrtes por Minas e deputado por Minas e Goiás (1823, 1826-1829 e 1834-1837), tendo falecido em 1835. Bulhōes, que foi seu companheiro e amigo, era sogro de uma de suas filhas e meio irmão do Marechal Joaquim Xavier Curado. Em 1831, Jardim foi nomeado presidente da província e em 1837 senador, falecendo em 1842 .

Além disso, era ligado ao Marquês da Palma, D. Francisco de Assis Mascarenhas, de quem sua mulher tivera dois filhos anteriores ao casamerto. Esses enteados, a quem dedicava afeição eram D. Francisco de Assis Mascarenhas, bacharel que com o duplo patrocínio do pai e do padrasto foi juiz de direito de Goiás, deputado por Goiás (1836 a 1847), presidente da província (1839-1845). Em 1847, D. José cedeu seu lugar de deputado a seu meio irmão (também goiano, filho de uma índia) D. Manuel, pois já então se achava nomeado desmebargador no Maranhão. 
A Sedição do Norte - Desde o século anterior o norte da capitania nutria um ressntimento contido, mas permanente, contra o governo e os homens de Vila Boa. Oprimido pelo fiscalismo colonial, os benefícios do govreno incidiam muito mais sobre o sul, cujos homens — próximos à administração — iam-se transformando em burocratas.

As primeiras décadas do século XIX acrescentaram mais razões a esse descontentamento. O retrato que Cunha Matos traça dessa região é de:olador. Pontes destruídas, edifícios públicos ruídos, arraiais quase desertos, pela população que se evadia do abandono e do isolamento. Especialmente a demora - ou omissão total em alguns casos - das autoridades da capital em socorrê-los dos ataques cada vez mais frequentes dos índios às suas fazendas, a forte taxação que incidia sobre o gado exportado e o fato de grande parte dos homens livres da capital serem funcionários sustentados pelos impostos arrecadados sobre seu trabalho, tornava os homens do norte conscientes da opressão que pesava sobre eles (23).

Além do ressentimento, eram muito pouco ligados ao sul da capitania. A predominância da pecuária - em confronto com o sul, onde a agricultura ainda era mais intensa - os identificava mais com o norte de Minas Gerais e com o oeste baiano, a comunicação pelos rios o- ligava ao Pará. E todo o norte da capitania estivera, por quase um século, vinculado às administrações diocesanas do Pará e Pernambuco.

Nesse clima permanente de irritação, haviam encontrado no Ouvidor Joaquim Teotônio Segurado o chefe de que necessitavam para expressar-se. A criação da comarca do norte e a instalação da Vila de São João da Palma, com sua câmara, já lhes dera certa impres:ão de autonomia.

Segurado encontrava-re em Traíras no início de setembro, quando recebeu notícias da crise de agosto na capital. Sua educação jurídica e o conhecimento que tinha da constitucionalização do governo

(23). - SDEG, Livro $1^{o}$ de registro d ecorrespondência do Govêrno tas Armas com as autoridades civis da Província (1823-1826), passimL Setor de Documentação do Departamento de Histó ia da FFLCH da USP, Microfilmes da Documentação do Museu das Bandeiras (Goiás), rolos 45 e 46 - saíla de gado. MATOS (Raimundo José da Cunha), "Corografia História da Província de Goiás, in Revista do Instituto Histórico e Geográfico Brasileiro, tonın 37, 1874 e tomo 38,1875 , passim. 
português, já predispunham a agir contra governantes impostos. Participando ainda do mesmo ressentimento que toda a região sentia contra o sul, a prisão do capitão Cardoso - eleitor do norte - a mando do governador, foi o fator desencadeante de sua decisão de não submeter-se mais ao governo de Goiás.

Conhecendo bem as rivalidades locais que poderiam dif cultar a rebelião, seguiu para Cavalcante (e não para Palma, sua residência) e em um dia instalou - exatamente um mês depois do fracassado levante da capital - um governo provisório independente de Goiás, com a aprovação popular. Lançando proclamaçōes que falavam de liberdade, declarou criada a província, abolidos os impostos e pedu que os arraiais elegessem deputados que viessem reunir-se em Cavalcante, onde dariam forma ao governo e escolheriam uma nova capital (24).

No fim de setembro o Capitão General tomou conhecimento de que um governo separatista havia sido instalado em Cavalcante. No dia 29 , convocando ao quartel-general todos os que tivessem qualquer parcela de autoridade, propôs o envio de força militar ao norte, para sufocar pelas armas a rebelião. A proposta foi aplaudida e aceita francamente. Mas no momento em que se designou o Tenente-Coronel Alexandre José Leite Chaves de Melo como sub-comandante da coluna, este levantou-se e qualificou a decisão de ilegítima e criminosa. O protesto fez que recuas`em e resolvessem consultar o Regente antes de qualquer decisão (25).

Pouco depois, em carta, Sampaio justificaria sua proposta af $r$ mando que por notícias, sabia que os chefes do movimento teriam sido influenciados pela situação do Nordeste brasileiro. Entretanto, correspondência recebida do Rio de Janeiro - recomendando evitar qualquer forma de violênicia - fez que repensa'se seu comportamen-

(24). - ALENCASTRE (José Martins Pereira de), op. cit., 126.129 e SDEG, Maço de Ordens e Decretos (1820-1824), doc. 28/1821. Mais tarc'e. a junta de govêrno provisório de Goiás, a quem a separação do norte atingira ruramente pelo brusco corte nos recursos provententes de impostos sobre a exportação do gado, acusaria Segurado de ser partidário de Portugal. Na realidade, não o preocupava muito o fato de o Brasil estar ou não vinculado a Portugal. Era declaradamente partidário de um governo constitucio nal, mas su 1 preocupação maior era colocar fim à dependência de sua região ao goverro do sul. Quanto à junta de Goiás, não poderia acusar ninguém de fidelidade a Portugal, pois ainda a 27 de agosto de 1822 lançou uma proclamação em cujo final saudava o rei, a assembléia luso-brasileira e o Regente. Cf. SDEG, Livro $1^{o}$ de Registro Geral (1820-1824), 113v-114. $3-12 v$.

(25). - SDEG, Livro de Oficios da Junta Interina para Lisboa (1822). 
to e reconsiderasse sua responsabilidade. Nessa mesma carta afirmava que incluíra entre seus planos abandonar a Província, se não conseguisse contornar as incompatibilades (26).

Limitando sua ação, o governador dirigiu uma proclamação aos habitantes do norte, na qual pedia confiança, pois embora houvessem sido oprimidos, chegara o momento de obter satisfação desde que se mantivessem fiéis. Nesse documento, recriminava o vigário de $\mathrm{Ca}-$ valcante, que julgava ser o cabeça da rebelião (quando, pelo contrário o padre, tímido, procurava fugir de Cavalcante para o sul a fim de jurar fidelidade a ele) (27).

Recebendo em Cavalcante essa proclamação, Segurado impediu que se torna'se pública, por já existir dissidência no governo. Ainda em outubro, procurou contornar os problemas que surgiam mudando a capital para Arraiais, preferida pela maioria dos representantes dos arraiais. Contra sua expectativa, a transferência acelerou a desagregação. O vigário de Cavalcante fugiu para Goiás - onde denunciou nominalmente todos os rebeldes - enquanto outros deixavam-se ficar em Cavalcante, desligando-se do movimento (28).

A Junta Interina - Em Goiás, em, outubro, Sampaio soube que D. Pedro autorizara a formação de juntas provisórias em Minas e Pernambuco e decidiu não opor-se mais à formação de uma semelhante na Província. Informou a Câmara de sua decisão, fixando a data de 3 de novembro para eleições.

Já estando em andamento os preparativos eleitorais, contentados os poucos dirsidentes, a situação alterou-se com a chegada de José Rodrigues Jardim, vindo do Rio de Janeiro, reassumindo sua cadeira de vereador, dirigiu-se à Câmara em sessão pública, recriminando a aceitação de uma eleição à qual não estariam presentes eleitores de toda província. Recebeu o apoio do juiz de fora e presidente, Manuel Antônio Galvão e foram unanimemente derrotados (29).

A 3 de novembro a junta terminou por não ser eleita. Tumultuou-se a reunião, a tropa permaneceu no recinto e insistia em votar,

(26) - ALENCASTRE (José Martins Pereira de), op. cit., 131.

(27). - SDEG, Livro $1^{o}$ de Registro Geral (1820-1824), 83v e ALENC.ASTRE (José Martins Pereira de), op. cit., 132-133.

(28). - SDEG, Maço de Ordens e Decretos (1820-1825), doc. 28.1821

e ALENCASTRE (José Martins Pereira de); op. cit., 129-130. $3-12 v$.

(29). - SDEG, Livro de Ofícios da Junta Inetrina para Lisboa (1822), 
ocorreram ameaças de agressão física e mais uma vez resolveram consultar o Regente (30).

Há indicações de que o governador, embora concordando com a eleição de uma junta, preferisse adiar o fato, à espera de ordem específica de $D$. Pedro. De outro lado, Jardim compareceu à reunião embora discordasse dela e tomou parte ativa nos tumultos, quase chegando a uma cena de pugilato com o Tenente-Coronel Costa Freire e também à ele não convinha que a junta fosse formada naquele momento.

Já em dezembro, o juiz de fora, abandonando a posição neutra em que se mantinha, passou a pregar a constituição imediata da junta. Ele e todos os vereadores estavam irritadíssimos com a atitude do ouvidor Paulo Couceiro que, atendendo petição dos conselhos de Santa Luzia e Meia Ponte, os autorizara a despender parte dos recursos que arrecadavam, em obras de reconstrução de prédios públicos. A Câmara recebia então, integralmente, todos os rendimentos dos arraiais da comarca e os aplicava livremente. A decisão do ouvidor contribuiu para aumentar a resistência contra o capitão general.

Nos últimos dias do ano, quando tudo indicava que a junta seria instalada com a anuência de Sampaio ou sem ela, este recebeu ofício de D. Pedro mandando não resistir à vontade popular. Que fosse formada a junta se as iniciativas locais o exigissem. Na noite de 29 de dezembro convocou o secretário Antônio Pedro de Alencastro ao palácio e pediu-lhe franqueza. Foi-lhe dito que militares e civis estavam unidos e rebelados, prontos a instalar novo governo, mesmo que fosse em praça pública. Diante disso, na manhã seguinte convocou todas as autoridades à Câmara, mandou que escolhessem a junta, e retirou-se.

Reunindo-e em sessão privada a Câmara resolveu que a ausência dos eleitores do interior permitiria apenas a escolha de uma junta administrativa provisória, que deveria responder pelo governo e preparar a eleição da junta efetiva.

Convocaram então quase meia centena de cidadãos, os que normalmente eram consultados em ocasiốes decisivas, e elegeram uma junta formada por Sampaio - presidente, Alencastro - secretário, Paulo Couceiro de Almeida Homem, capitão Inácio Soares de $\mathrm{Bu}-$ lhões, vigário da vara Francisco Xavier dos Guimarães Brito e Cos-

(30). - Idem, idem. 
ta e o coronel Luís da Costa Freire de Freitas. Apenas os dois últimos não obtiveram a unanimidade dos votos (31).

Jardim não compareceu a essa reunião, cedendo lugar ao suplente. Após o revés público de 31 de outubro e os tumultos de 3 de novembro, recolheu-se e passou a agir com maior habilidade. Sabia que o capitão general ainda impunha respeito e, sendo as eleições convocadas por ele, dificilmente deixaria de receber os votos da maioria, que tinha muito pouca consciência do processo que envolvia o país. De acordo com Bulhões, Alencastro, Galvão e outros, deixou de comparecer e aceitaram a eleição de Sampaio e do que o apoiavam. Instalada a junta, começaram a usar contra eles de todas as armas de que dispunham. Os muros amanheciam cobertos de pasquins ofensivos, cartas anônimas grosseiras eram enviadas continuamente e circulavam de mão em mão. Mas, se tomar o governo era a meta, a lưa aberta pela Independência não se tornou clara nessa ação.

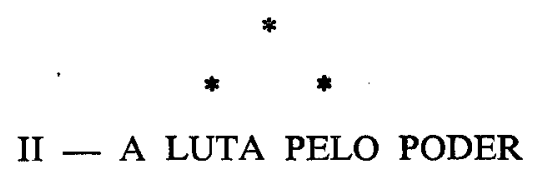

O Primeiro Expurgo. - Já no primeiro dia do ano, reunindo-se a junta, Bulhões provocou uma longa discussão. Contestava o direito do ouvidor de acumular funções.

No dia seguinte, Sampaio - informado da verdadeira situação política e tendo lido alguns pasquins e cartas anônimas - reuniu-se com os membros da junta para prestarem os juramentos de fidelidade. Estando todos presentes, pediu afastamento do cargo, sendo-lhe negado. Concordou em permanecer, mas mandou desmuniciar a tropa para evitar qualquer possibilidade de violencia.

Se o presidente perdera o ânimo, a indignidade dos ataques irritara o ouvidor. No dia 7 de janeiro Paulo Couceiro representou ao Regente contra a Câmara da capital, acusando os vereadores de apropriação indébita dos recursos dos arraiais e de má administração dos seus próprios recursos.

(31). - Idem, idem, 1-12v. ALENCASTRE (José Martins Pereira de), op. cit., 135-139; BRASIL (Antônio Americano do), Súmula de História de Goiás, Goiânia, Departamento Estadual de Cultura, 1961, $2^{\text {a }}$ edição, 85; REIS (Artur Cezar Ferreira), "Goiás". in História Geral da Civilização Brasileira, São Paulo, Difusão Européia do Livro, $4^{\circ}$ volume, 186. 
Nesse mesmo dia os opositores revidaram, durante a reunião da junta. O secretário Alencastro leu, na presença do presidente Sampaio, uma escabrosa carta anônima que o insultava fortemente e terminava por prevenir os membros da junta contra ele, cuja intenção seria envenená-los a todos durante um banquete, no dia seguinte.

Pedindo a palavra, Sampaio lembrou que já pedira afastamento do cargo anteriormente e declarou-se afastado a partir daquele momento. Aceito o fato consumado, recusaram-se a considerar pedidos semelhantes, encaminhados pelo ouvidor e pelo coronel Costa Freire. E ainda na mesma reunião, sutilmente, elegeram Paulo Couceiro para ocupar a presidência por trinta dias (32).

Jardim e seus companheiros desejavam evitar precipitações. $O$ afastamento simultâneo de três membros da junta faria que os restantes caíssem em descrédito. Era mais seguro promover a eliminação sucessiva, levando-os a se afastarem um de cada vez. Assim, no dia seguinte uma sóbria comunicação foi levada a público, informando que Paulo Couceiro assumira a presidência, póis Sampaio renunciara para ajudar a tranquilizar a província.

Dias depois Sampaio pedia visto em seus passaportes, para deixar a província e requeria da junta uma certidão informando todos os fatos que procederam seu afastamento, inclusive cópia das acusaçóes que the haviam sido feitas. Esta foi-lhe negada, apesar do protesto de Couceiro e Costa Freire. Diante disso, o ouvidor-presidente negou-se a comparecer a novas reunióes, exonerou-se dos cargos que ocupava e aprontou-se para abandonar a provincia.

A atitude incontornável de Couceiro assustou os membros da junta, que então tomaram uma atitude duplamente falsa: expediram uma proclamação ao povo afirmando que ele resolvera exonerar-se de seus cargos - sem outra explicação - e instauraram inquérito contra ele, remetendo imediatamente os autos para Lisboa (33).

Em ofício posterior às Cortes (34), a junta justificou o afastamento do ouvidor-presidente com acusações desconcertantes. Considerou inicialmente a sua responsabilidade pela formação de um go-

(32). - SDEG, Livro de Oficios da Junta Interina para Lisboa (1822), $2 \mathrm{v}-12 \mathrm{v}$ Livro $1^{\circ}$ de Registro Geral (1820-1824), 85-86.

(33). - SDEG, Livro $1^{\circ}$ de Registro Geral (1820-1824), 86v-87v; Livro de Ofícios da Junta Interina para Lisboa, 13v-17 e ALENCASTRE (José Martins Pereira de), op. cit., 144-145.

(34). - Nos últimos meses de sua permanência, Sampaio já não pedia ordens a Lisboa, mas a junta voltou a fazê-lo. 
verno separatista ao norte; esse governo teria surgido em consequência da prisão do capitão Cardoso e colocara em dificuldade os "fiinos-da-folha", impossibilitados de receber seus salários; em seguida « vvantou contra Couceiro suspeição de ser instrumento do antigo capitão general, o qual criticava abertamente as Cortes de Lisboa; finalmente acusou o ouvidor de elogiar "suspeitosamente" o Regente, afirmando em público que D. Pedro não deveria retornar a Lisboa, mas permanecer no Brasil (35).

Com o afastamento de Couceiro, a presidência foi entregue ao vigário da vara, Francisco Xavier dos Guimarães Brito e Costa, que alguns dias depois, apoiado pelos demais, nomeou o coronel Álvaro José Xavier para o comando da tropa. Isso feriu o coronel Costa Freire, que renunciou ao seu cargo na junta, concluindo o xepurgo.

Nos primeiros dias de janeiro, a junta de Goiás enviara um ofício à Câmara de São João da Palma comunicando sua instalação e convidando-a a reunir-se ao sul.

Já nesse início de ano a situação política do norte era crítica. Segurado havia partido para Lisboa, via Belém, e deixado em seu lugar o tenente-coronel Pio Pinto de Cerqueira, que não tinha condições para conduzir a administração.

O homem que poderia chefiar o norte era o capitão Cardoso. Mas ele permanecia em sua fazenda de Arraiais, isolado de tudo, pois só aceitaria unir-se a quem estivesse claramente favorável à Independência .

Com a viagem de Segurado para Portugal, o tenente-coronel Cerqueira transferiu a capital, de Arraiais para Natividade (36). Isso viria a provocar maior desagregação no grupo governante do norte.

No sul, à tranquilidade de fevereiro - mês de intensas chuvas - sucedeu um março agitado. As idéias republicanas de Galvão, agora ouvidor, começavam a encontrar algum eco. Uma amotinação em Jaraguá inquietou a junta, que evitou agir e limitou-se a expedir ofícios pedindo confiança e subordinação.

A partir daí, o grupo que se mantivera unido para controlar a junta, começou a cindir-se, com Galvão e Alencastro discordando da

(35) . - Na verdade, desejavam apenas justificar-se perante a metrópule, com argumentos verdadeiros ou não, pelas atitudes tomadas.

(36). - REIS (Artur Cezar Ferreira), op. cit., 187 e ALENCASTRE (José Martins Pereira de), op. cit., 153-154. 
limitação de objetivos dos demais, que não chegavam à compreensão do processo político nacional. Essa incompreensão está expressa na proclamação publicada a $10^{\circ}$ de abril - pouco depois de saberem que D. Pedro decidira permanecer no Brasil. Comunicava o fato ao povo e informava que iriam agradecer ao Regente em nome dos goianos, reconhecendo o sacrifício feito para garantir os direitos brasileiros. Viam a permanência do príncipe

“. . . como vínculo indissolúvel que prende um a outro hemisfério português ..." e concluiam protestando lealdade às Cortes e a D. João (37).

Na mesma semana, receberam resposta do ofício enviado à Câmara de Palma. Diziam os vereadores do norte que os meses de isolamento e independência thes haviam mostrado quão longas eram as 140 léguas que os separavam de Goiás. E em tom levemente sarcástico, respondendo ao convite de reunião, afirmavam que: sendo a Província da Palma mais antiga que a Província de Goiás, seria mais lógico reunirem-se os do sul aos do norte (38).

A Evolução do Quadro Político no Sul. - A eleição do governo provisório a 8 de abril, marcou o momento da definição política da província. O grupo vitorioso, depois de firmar-se e reunificar comarcas, viria a consolidar-se no poder durante o período regencial e cristalizaria - ao longo do Segundo Reinado - um estamento político-burocrático concentrado na cidade de Goiás e uma conjuntura política que só começaria a ser transformada mais de um século depois.

Em 1824, Cunha Matos (39) comentaria em ofício, o decreto de 20 de outubro de 1823. Essa lei extinguia as juntas de governo, criava as presidências de província e os conselhos administrativos. Não se pode saber até que ponto ia a compreensão que o Coronel tinha das contradições sociais que afloravam, mas ele viu claramente o conflito de interesses entre um colegiado que deveria representar a sociedade regional e um presidente estranho a esse conjunto, cuja

(37). - SDEG, Livro $1^{\circ}$ de Registro Geral (1820-1824). ALENCASTRE (José Martins Pereira de), op. cit., 147.

(38). - ALENCASTRE (José Martins Pereira de), op. cit., 153-154

(39). - Raimundo José da Cunha Matos foi governador das armas da província de 1823 a 1826 . Nesse período foi promovido a general e eleito derutado pela província (1826). 
missão era ordenar a vida provincial conforme os interesses do governo imperial (40).

Desde janeiro de 1822 , quando deixaram a província Sampaio e Couceiro, algumas mudanças alteraram o panorama político da capital. Restavam na junta o seu presidente, o vigário Brito e Costa, que se colocava sempre ao lado da situação (41); Alencastro, cujas idéias o afastavam dos demais, juntamente com o ouvidor Galvão; e Bulhões, que permanecia fial a Jardim .: Este assumira a Procuradoria da Fazenda Nacional e Galvão exercia cumulativamente os cargos de juiz de fora, presidente da Câmara e ouvidor, por não existir na cidade outro bacharel.

$O$ Governo Provisório. - Na semana das eleições, as ações foram planejadas pelo grupo de Jardim, de modo a controlarem o colégio eleitoral. Foram cautelosos porque os republicanos de Galvão e Alencastro estavam excitados pelo "Fico" e também por temerem qualquer iniciativa do coronel Costa Freire, que ainda comandava uma das corporações militares.

No dia 8 de abril reuniram-se na Câmara dezesseis eleitores de toda a comarca, tendo conhecimento das candidaturas à presidência . Eram candidatos o ouvidor Manuel Antônio Galvão pelos radicais, o coronel Álvaro José Xavier pelo grupo de Jardim e Raimundo Nonato Hyacinto como nome de acomodação que permitiria conciliar divergências. Controlando dez dos dezesseis votantes, uma coalisão Goiás-Meia Ponte elegeu o governo que desejava.

O governo provisório ficou constituído por Ålvaro José Xavier - presidente (10 votos), José Rodrigues Jardim — secretário (9 vo-

(40). - Demonstrando compreensão do comportamento político provincial, criticou a lei, dizendo: “. . . compõe-se um governo policéfalo muito pior do que aquele que se pretendeu extinguir; o Excelentíssimo Presidente da Provincia fica constituído um miserável brinco ou autômato de meia dúzia de romens seus nesessários inimigos, entre os quais pode ser que vejamos Manuel Leite, Manuel Mateus, José Bernardino, Vidal, e outros rábulas do mesmo estofo, que tem loquela para conduzirem o povo aos interesses deles . . ." Cf. SDEG, Livro $1^{o}$ de correspondência do Govêrno das Armas com as autoridades civis da Província (1823-1826), 78v .

(41) - - Seu procedimento foi satirizado em verso por Silva e Soltza. Cf. AlenCASTRE (José Martins Pereira de), "Traços Biográficos de Silva e Souza", in Revista do Instituto Histórico e Geográfico Brasileiro, tomo 30, $1867,241-256$.

(42). - O distrito de Goiás tinha cinco eleitores da cidade e um de Arta, Meia Ponte tinha três, Santa Luzia dois, Santa Cruz dois (um dos quais não compareceu), Pilar dois, Traíras um, São Felix um, não comparecendo o eleitor de Crixás. 
tos), Raimundo Nonato Hyacinto (8 votos), João José do Couto Guimarães (10 votos), Joaquim Alves de Oliveira (9 votos), Luís Gonzaga de Camargo Fleuri (10 votos), Inácio Soares de Bulhões (11 votos). Poucos dias depois o comandante de Meia Ponte; Joaquim Alves de Oliveira, encaminhava à junta seu pedido de afastamento des:e e de qualquer outro encargo (43).

Assim que os resultados foram aunciados, o ouvidor fez violento protesto público contra eleitores e eleitos, passando a fazer a partir de então, oposição ao governo (44).

Para os que acabavam de ser eleitos, a ira de Galvão não constituia perigo imediato. Temia-se mais ao tenente-coronel Costa Freire que, embora discordasse politicamente do ouvidor, era seu compadre e a partir daquele momento estariam ambos unidos pela marginalização política.

No mesmo dia, tal era o receio, neutralizaram o tenente-coronel. $\mathrm{Na}$ reunião em que todas as autoridades prestariam juramento de fidelidade ao novo govreno, apresentando-se Costa Freire para a formalidade, compareceu perante a junta um grupo de dragões e pedestres que, em presença dele, o denunciou por dupla tentativa de seđição da tropa. No mesmo instante foi afastado do comando e instaurou-re inquérito contra ele, sendo-lhe dados oito dias para abandonar a província.

Contestação ao Regime - Apesar dessa demonstração de força ou em função dela - pois a violência contra Costa Freire desagradara a muitos - Galvão e Alencastro passaram a agir ativamente, fazendo comícios e promovendo reuniões. A rebeldia que se havia pressentido em Jaraguá reanimou-se e apareceram outros focos em alguns arraiais. Discursando imprevistamente em reuniões cívicas e religiosas, lançando pasquins e escrevendo cartas, procuravam convencer o povo de que a permanência de uma cabeça coroada no Brasil mantinha a possibilidade de retorno do despotismo colonial.

Suportando os ataques verbais dos opositores, o governo provisório procurava firmar-se no poder e aguardava oportunidade para

(43). - SDEG, Maço de Ordens e Decretos (1820-1825), certidões encaminhadas à junta pelo sargento-mor Joaquim Alves de Oliveira. BRASII. (Antônio Americano do), op. cit., 86. ALENCASTRE (José Martins Pereira de), "Anais da Província de Goiás", in Revista do Instituto Histórico e Geográfico Brasileiro, tomo 28, 147-151. REIS (Artur Cezar Ferreira), op. cit., 186-187.

(44). - SDEG, Livio $1^{\circ}$ para a Secretaria da Justiça (1822-1824), 1. 
eliminá-los. Entretanto, consolidar a autoridade não era tarefa simples. Em julho, problemas surgidos em Pilar forçaram o envio do padre Gonzaga ao local e sua ausência seria sentida nos dias seguintes, quando a crise atingiu a fase aguda.

Precavidos, os membros do governo provisório haviam comunicado à Secretaria da Justiça as perturbações que Galvão e Alencastro provocavam, secundados pelo escrivão de ausentes Gabriel Getúlio Monteiro de Mendonça. Sentindo-se assegurados por esse aviso prévio, agiram prontamente pouco depois, para garantirem-se no poder.

Reunidos novos eleitores em agosto, para a escolha dos deputados à Assembléia, foram eleitos: Manuel Antônio Galvão, Antônio Pedlro de Alencastro e para a suplência, Gabriel Getúlio Monteiro de Mendonça.

Perante a reação eleitoral, o governo apelou para uma atitude radical. Convocadas a Câmara e as corporações militares, diante delas declarou, nulas as eleições, fez nova convocação coativa dos eleitores (parte deles deixara de comparecer) e excluiu os eleitos do colégio eleitoral.

Galvão, Alencastro e Gabriel Getúlio, que controlavam a Junta da Fazenda - da qual eram respectivamente presidente, vogal e secretário - reunidos na sede da mesma com seus partidários, esboçaram uma reação. Declararam ilegítimo o governo provincial e negaram publicamente obediêncina à Regência .

O Segundo Expurgo. - A tropa, mobilizada e excitada por membros do governo ,preparou-se para expulsá-los pelas armas. A pequena cidade viu-se convulsionada por dois governos que se contestavam e pela mobilização dos contingentes militares, que se mantinham nas ruas, controlando todos os pontos estratégicos.

Nesse momento, Jardim e Gonzaga (que retornara), sentindo haver retomado o controle da situação e a inconveniência e precipitação dessa atitude, forçaram o recolhimento da tropa, preferindo agir politicamente.

Entre os dias 6 e 8 de agosto fizeram baixar diversas portarias demissionárias. Afastaram Alencastro da secretaria do expediente, que passou a ser exercida cumulativamente por Jardim. Como também fosse procurador da Fazenda (Jardim deixara o cargo ao ser eleito secretário de governo) promoveram a reaproximação com o padre 
Luís Bartolomeu Marques, nomeando-o para esse cargo. Em seguida mandaram que Alencastro abandonasse a província em oito dias, conforme exigência que a oficialidade, instruída, fizera.

No dia seguinte o ouvidor, ainda não demitido, tentou uma última reação, convidando os republicanos a se reunirem. Foi imediatamente afastado do cargo e, por ofício, a junta mostrou-lhe a inconsequência do gesto. Sentindo-se derrotado, Galvão aceitou um acordo que the foi proposto. Recebeu todos os seus vencimentos e uma escolta para acompanhá-lo até os limites da província.

Considerando a menor responsabilidade do escrivão Gabriel Getúlio Monteiro de Mendonça, suspenderam-no de suas funções e ordenaram-lhe que se retirasse para sua fazenda. A mesmo ordem foi dada ao escrivão da Fazenda, José José de Azevedo Noronha e Câmara, acusado de conivência.

Em ofício enviado pouco depois à Secretaria da Justiça, a junta da governo acusou Galvão de insubordinação para com a Regência, pretensõts de independência do Rio de Janeiro e ligações com grupos radicais da Bahia, à qual Goiás se uniria caso ele fosse eleito presidente (45).

Feitas novas eleições, foram escolhidos o padre Silvestre Alves da Silva (vigário de Traíras que unira sua freguesia ao Sul) e o sargento-mor Joaquim Alves de Oliveira (46).

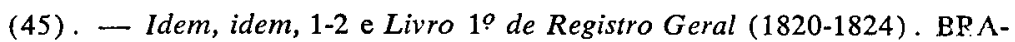
SIL (Antônio Americano do), op. cit., 89-94.

(46) . - A escolha do sargento-mor é de difícil explicação. Tinham em mãos um dorumento assinado por ele e registrado no tabelionato de Meia Ponte, informando que era chagásico, artrítico, gonocócico e, provàvelmente, prostático, não tendo condiçóes de viajar. Talvez, eleger Joaquim Alves fosse mais seyuro que correr o risco de ter de aceitar um indesejavel como deputade ou de ter que enfrentar nova crise. Nenhum membro da junta poderia ser escolhido, pois as circunstâncias não permitiriam o afastamento de ninguém. Já pensavam em mandar Gonzaga ao norte para promover a reunião das comarcas; Couto Guimarães e Hyacinto eram fazendeiros e funcionários, ambos portugueses, a quem não entregariam o governo; Joaquim Alves não exercia o cargo; o presidente Xavier, como Bulhões, era idoso (ambos faleceram em 1825) e apesar de respeitados não tinham condiçōes para governarem sozinhos. Na ausência de Gonzaga restaria apenas Jardim em Goiás, como executivo efetivamente capaz. 


\section{III. - A REUNIFICAÇÃO DA PROVINCIA.}

A Desagregação do Governo do Norte. - Com a transferência da capital para Natividade, a discórdia ampliou-se ainda mais. $O$ tenente-coronel Pio Pinto de Cerqueira não era homem de contornar problemas ou buscar soluções de conciliação. Pouco depois de transferir-se, com os membros do seu governo, para Natividade em virtude de dissidências na Palma, elevou a nova capital à categoria de vila, transferindo para lá a Câmara de Palma e seus arquivos. Como os vereadores, liderados pelo ouvidor Febrônio José Vieira Sodré, se rebelassem, destituiu o ouvidor e assumiu cumulativamente a função. Em seguida expediu uma coluna militar para prender a todos, dando ordens para que sessenta soldados permanecessem guarnecendo Palma.

Os vereadores, conseguindo fugir aos soldados de Cerqueira, refugiaram-se em Arraias. Aí receberam apoio e proteção, mas não do capitão Filipe Antônio Cardoso. Este, partidário da Independência total, apoiava o governo da Natividade, que nessa época já defendia as mesmas idéias. A ausência de Segurado e a presença de Cardoso haviam feito Cerqueira e seus homens evoluirem, chegando a uma posição independencista clara. Além disso, tanto Cardoso como Cerqueira estavam influenciados por vislumbres de idéias republicanas absorvidas através do sertão, vindas de Pernambuco e da Bahia.

Assim, sem qualquer organicidade, existia um governo provincial autolegitimado, sediado em Natividade, partidário da Independência e que contava com o apoio de um dos homens mais influentes da região. Em Arraias estavam os vereadores da Palma, apoiados pela maioria dos homens do arraial, que não obedeciam ao governo da Natividade mas também recusavam subordinação ao governo provisório de Goiás e não manifestavam convicções claras quanto à Independência .

A Missão Unificadora de Gonzaga. - Em Goiás, ultrapassada a crise de agosto, o governo começou a recompor a administração províncial. Apesar das notícias que tinha do Rio de Janeiro, o separatismo do norte ocupava mais sua atenção.

Em outubro, depois de ouvirem as pessoas que conheciam mehor o norte, resolveram enviar para lá o padre Gonzaga, autorizado a agir livremente para promover a reunião das comarcas. Iria acompanhado de escolta militar comandada pelos tenentes-coronéis José Antônio Ramos Jubé e Alexandre José Leite Chaves de Melo. 
Enquanto preparavam a expedição, receberam ofício da Secretaria da Justiça, informando que. D. Pedro aprovara seu procedimento relativo a Galvão e seus companheiros e mandando que os remetessem presos ao Rio de Janeiro. Como Galvão e Alencastro houvessem deixado a província, remeteram sob escolta a Gabriel Getúlio Monteiro de Mendonça e liberaram João José de Azevedo Noronha e Câmara, autorizando-a a retornar à capital e reassumir seus cargos (47).

A 15 de novembro o padre Gonzaga deixou Goiás rumo norte com sua escolta. Dez dias depois soube-se na capital da Independência e da aclamação de D. Pedro a 12 de outubro. Essas notícias chegaram a Gonzaga no final de dezembro, quando estava estacionado em Traíras.

Quase simultaneamente, os tropeiros do capitão Cardoso trouxeram-lhe as mesmas notícias através de jornais e gazetas da Bahia (48). Deixando sua fazenda, seguiu para Arraias, onde promoveu as solenidades de juramento de fidelidade ao Imperador no primeiro dia de 1823. Imediatamente partiu rumo a Cavalcante, onde iá estacionara a vanguarda da escolta do padre Gonzaga. Transmitou ao tenentecoronel Chaves de Melo as notícias e resolveram aguardar a chegada de Gonzaga.

No dia 20 de janeiro, após as solenidade o capitão Cardoso protestou publicamente, em nome do povo do norte, contra a reunião das comarcas. Afirmou então que Natividade havia representado ao Imperador, a quem competia decidir a respeito. A re posta de Gonzaga foi contundente: mandou prendê-lo e remeteu-o imediatamente para Goiás, de onde seguiu para a Corte.

Em Arraias, a aproximação de Gonzaga - conhecida a notícia da prisão pública de Cardoso - fez que os vereadores da Palma se acovardassem e procurassem sua simpatia. Utilizando uma portaria de 12 de novembro anterior, assinada por José Bonifácio (que mandava processar todos os que conspirassem contra o regime), oficiaram - a 16 de fevereiro - ao ouvidor Vieira Sodré, ordenando a devassa (49).

(47). - SDEG, Livro $1^{o}$ de Registro Geral (1820-1824) e Maço de Ordens e Decretos (1820-1825). ALENCASTRE (José Martins Pereira de), op. cit., 187-188; BRASIL (Antônio Americano do), op. cit., 89-94; REIS (Ârtur Cezar Ferreira), op. cit. 160.

(48). - SDEG, Livro de Registro de Ofícios Expedidos (18:2.:823), 1v. ALENCASTRE .(José Martins Pereira de), op. cit., 160.

(49). - Foram pronunciados: Pio Pinto de Cerqueira, Felipe A:tô io Cardoso, Silvério José da Silva Rangel, José Bernardino de Sena Ferreira, Lúcio Luís Lisboa, Manuel Mateus Ferreira e outros. Cf. ALENCASTRE (José Martins Pereira de), op. cit., 162-163. 
Depois de controlar a situação em Cavalcante, Arraias e Palma, Gonzaga seguiu para Natividade, onde chegou a 21 de março. No princípio de abril estava dissolvido o último núcleo rebelde e presos os seus chefes. Apesar disso, durante longo tempo, continuou a sobreviver uma revolta surda da população do norte contra o governo e os homens de Goiás.

As Províncias do Norte. - A missão do padre-deputado deveria ter-se encerrado a esta altura, mas prolongou-se até o final de 1823 $\mathrm{cm}$ virtude de notícias que chegaram ao seu conhecimento pouco depois de ter controlado Natividade.

As agitações no Pará, Maranhão e Piauí, penetrando sertão adentro, haviam atingido o extremo norte da província e Gonzaga sentiu-se forçado a deslocar-se para essa região, pretendendo descer o 'Tocantins (50).

A resistência portuguesa e a agitação nas províncias do norte (e também a instabilidade política de Goiás) levaram o governo imperial a apressar a nomeação do coronel Raimundo José da Cunha Matos para o Governo das Armas de Goiás.

Chegando à capital em junho, Cunha Matos verificou a situação das instalações militares da cidade e seguiu para o interior a fim de inspecionar as guarnições dos arraiais do sul. Tomando conhecimento da situação no extremo norte, iniciou preparativos visando seguir para a região à frente de 440 homens. As notícias enviadas por Gonzaga o alarmaram.

O território goiano estava em calma, mas as regiões limítroìes, convulsionadas. O sargento-mor Paula, partidário de Portugal, havia ocupado Alcântara e forças de Oeiras haviam travado batalha contra as de Caxias, deixando baixas superiores a mil homens. Oeiras pedira reforços ao tenente-coronel Lustosa, comandante de Paranaguá, mas os homens que enviara encontraram-se em caminho com o grupo guerrilheiro chefiado por Germano e embora não houves:em sido derrotados, haviam sofrido sérias baixas (51).

(50). - SDEG, Livro $1^{o}$ de Registros de correspondências do Gov'êrno dos Armas com as autoridades civis da Província (1823-1826), 4v-5.

(51). - Embora os registros da correspondência de Cunha Matos forneçam alguns detalhes (como sua opinião sobre a periculosidade do sarye tomor Paula, por ser oficial de $1^{\text {a }}$ linha), alguns personagens - como o chefe de guerrilhas Germano - e episódios permanecem bastante obscuros. Cf. SDEG, Livro $1^{o}$ de Correspondência do Govêrno das Armas com as autoridades civis da Provítcia (1823-1826), 37-39. 
O que mais preocupava Cunha Matos era a informação de que Gonzaga estava decidido a descer o Tocantins em direção ao Pará levando consigo o tenente-coronel Jubé - atitude que qualificava de irresponsável e imprudente, pois este era o único oficial em todo o norte goiano capacitado para comando - podendo ser presos pelas guarnições paraenses.

Suas preocupações o levaram a desejar seguir imediatamente para o norte, enquanto o governo civil considerava desnecessária a expedição.

Alguns fatores condicionavam a atitude do governador das armas fazendo-o sentir-se compelido a partir. A inatividade era contrária à sua formação e sua personalidade, sua experiência militar anterior deformava as dimensões dos problemas em uma região que não conhecia e, por ser português, não desejava ser acusado de omissão perante qualquer forma de contestação à Independência política do Brasil. Em diversos ofícios enviados ao governo provisório, dejxou clara a sua preocupação quanto à possibilidade de ser acu ado de traição, caso não empregasse sempre todos os recursos postos à sua disposição, para garantir a tranquilidade e integridade do Império.

O governo civil, por seu lado, desaconselhava a expedição por entender que a tranquilidade interna da província era o limite da suas responsabilidades relativas à segurança nacional. E mais, preocupavase com os consideráveis gastos que deveriam ser feitos e que uitrapassariam em muito as reservas financeiras e a elasticidade - já reduzida - do crédito da administração provincial.

Em pouco tempo Cunha Matos desfaria tais argumentos. Em ofício ao Ministra da Guerra, mostrou que caso as forças de resistência paraenses e maranhenses marchassem para o sul, tomariam com facilidade uma enorme área de Goiás que se transformaria numa cunha divisora do território nacional. Convencido, o ministro mandou armar e municiar as tropas do coronel. O outro setor dos empenhos financeiros - sustento e soldo da tropa - foi provido pelo próprio Cunha Matos. Nas localidades onde se aquartelava, coagia os agentes da Fazenda a cobrarem rigorosamente as dívidas fisca.s acumuladas por diversos anos, e com isso conseguiu sustentar a tropa e pagar regularmente soldos e gratificações. Agindo assim para satisfazer interesses militares específicos, contribuiu para dinamizar mecanismos fazendários que - sobretudo ao norte da província - se haviam paralisado com as agitações políticas que já duravam dois anos. 
Além das agitações, a resistência passiva do norte à ação fiscal era fruto de um forte interligamento de interesses e famílias - os agentes da. Fazenda não agiam contra parentes, amigos e compadres - e da esperança que mantinham, de que a qualquer momento o Imperador terminasse por aprovar a separação das comarcas. As.sim, ou deixariam de pagar ao governo de Goiás, ou a sonegação temporária beneficiaria seu próprio governo. Mas a essa altura embora ainda não o soubescem - D. Pedro já declarara ilegal a iniciativa separatista, ajuntando conciliadoramente à decisão, a promessa de que o assunto seria encaminhado à Assembléia Geral para delib:ração parlamentar (52).

A Expedição Cunha Matos. - Partindo de Goiás a 20 de setembro de 1823, Cunha Matos dividiu suas forças em cinco divisões a serem postadas em Porto Real, Duro, Taguatinga, Salina se Cavalcante (onde ele próprio ficaria). Depois de estacionär em Pilar, seguiu para Traíras, onde foi informado de que as agitações haviam recomeçado em alguns arraiais.

Gonzaga, que permanecera em Natividade, descera o Tocantins em direção ao Pará. Avisado sobre o reinício das agitações, retrocedera para contê-las. Recebera também notícias de que em Flores, Arraias e outras localidades se havia festejado uma nova separação, fruto de boatos espalhados por José Bernardino de Sena Ferreira, de regresso ao Rio de Janeiro (53).

Atento às agitações internas e aos problemas das províncias do norte, Cunha Matos preferiu seguir de Traíras marginando o Tocantins, que lhe daria transporte rápido em caso de urgência. No final de outubro, aquartelado à margem direita desse rio, comunicou ao governo que o norte estava agitado pela notícia de que o Imperador não aprovara a separação. E ainda, que a colônia militar de Sãu João das Duas Barras (na confluência do Itacaiunas com o Tocantins), controlada por guarniçōes paraenses, tivera seus contingentes ampliados e que as margens do rio estavam guarnecidas por peças de artilharia.

(52). - SDEG, Maço de Ordens e Decretos (1820-1825), portaria de 23 de junho de 1823. Estando no Rio de Janeiro o padre Silvestre Alves da Silva, que conhecia bem o norte de Goiás, talvez tenha informado do perigo d: separação, pelas afinidades entre os goianos do norte e os paraenses.

(53). - SDEG, Livro $1^{\circ}$ de Registros da Correspondência do Guvîrno das Armas com as autoridades civis da Província (1823-1826), 52-54. 
O tenente-coronel Jubé descera o rio e fôra preso logo após desembarcar, por ter-se recusado a retirar uma b-açadeira que usava, com as cores do Brasil. Apenas seus canoeiros índios haviam conseguido retornar, burlando pela madrugada a vigilância dos sentinelas de beira rio.

No Maranhão, forças b:asileiras secundadas por um grupo de civis e 250 apinajés, todos da povoação goiana da Carolina, haviam combatido as tropas do sargento-mor Paula, con reguindo sua rendição e, posteriormente, o executando e a muitos de seus homens (54).

Apesar das notícias, seguiu para Cavalcante, onde permaneceu estacionado até o final do ano. Em novembro, um correio da divisão de Porto Real o informou de que o Pará e Maranhão se haviam submetido há alguns meses e que um eclesiártico, um coronel e um capitão de milícias subiam o Tocantins como enviados dessas províncias, com destino ao Rio de Janeiro, onde se apresentariam ao Imperador para jurar-lhe obediência (55):

Em janeiro de 1824 Gonzaga retornou ao sul e Cunha Matos permaneceu em Cavalcante - sem nunca entrar em ação - sempre sobre saltado por notícias trazidas por mascates e condutores de boiadas e tropas. Ora eram informações sobre convulsões em Pernambuco, ora boatos que percorriam o sertão, sobre a presença de $D$. Miguel em Recife, à frente de vinte mil homens.

Em maio iniciou uma ronda de inspeção às guarnições dos registros fronteiriços. De Cavalcante seguiu para Arraia e daí, a Taguatinga e São Domingos. Regressando a Arraias, partiu para Conceição e Natividade. Desceu então até Carolina, que fôra sitiada pelos apinaiés. Mais uma vez colocou as tropas em prontidão por causa do reinício das agitações no Pará.

Essas agitações haviam intensificado a migração para o nor e da província e ambas - agitação e migração - reativado as aspirações separatistas, já então voltadas para a possibilidade de anexação ao Pará.

Com o declínio da tensão, iniciou viagem de retorno à capita! em agosto, e em setembro já se encontrava em Traíras (56).

(54). - Idem, 55-55v.

(55). - Idem, 59.

(56). - Idem, 70v-99v. 


\section{CONCLUSÕES.}

1. - Durante a fase aguda do processo de independência, Goiá já não detinha importância política, pelo desaparecimento da economia mineradora.

2. - A crise de transição para uma economia agrária alienara a capitania do conjunto da vida nacional. A debilitação dessas articulações e o declínio da vida "urbana" - com a dispersão da população por um vasto território - impediam que a maioria absoluta dos habitantes tivesse acesso, ou pudesse compreender, ao que se pas ava fora, e mesmo dentro, dos limites físicos da província.

3. - O diminuto estamento senhorial-burocrático do sul encontrou no processo de independência a oportunidade de expressar seu descontentamento contra uma administração que não satisfazia as solicitações de uma sociedáde agro-pecuária, desde que estruturada para governar e fiscalizar uma sociedade mineradora. Virtualmente suas aspiraçōes políticas limitaram-se ao desejo de auto-dirigir-se e esse foi o sentido que deram à sua ação política.

4. - O ainda mais diminuto estamento senhorial-burocrático do norte, utilizou o processo de independência para dar expressão política ao seu descontentamento com a admini tração, e mais especificamente contra sua suieição a um governo regional instalado no sul, do qual estavam desvinculados pelas suas articulações sócio-econômicas e pelos condicionamentos ecológicos, que os aproximavam mais do oe te baiano e do Pará.

5. - Tornar o Brasil independente de Portugal foi uma preocupação sensível apenas em pequeno número de homens, os quais em momento algum expressaram o pensamento político dominante.

\section{INTERVENÇÃO.}

Da Profa. Cecília Maria Westphalen (da Universidade Fede:al do Paraná).

Diz que, a exemplo do que já dissera a respeito da Independência no Paraná, verificara a certeza da afirmação de Saint-Hilaire de que o revolucionarismo no Brasil caracterizava-se pelo dese o de emancipação do poder menor em relação ao poder maior. No mesmo ano, em 1821, quando por ocasião do Juramento às Bases da Constituição, verificou-se em Paranaguá, a Conjura separatista de Floriano Bento Viana, objetivando a separação da 5.a Comarca, porém sem consequências imediatas. 